\title{
PENGARUH KOMPENSASI, KEPEMIMPINAN DAN LINGKUNGAN KERJA TERHADAP KEPUASAN KERJA PADA PT. JNE EXPRESS
}

\author{
Hendri Jopanda \\ *Dosen Tetap FEB Universitas SatyaNegara Indonesia Jl.Arteri Pondok Indah No.11 Jakarta \\ hjopanda@.yahoo.com
}

\begin{abstract}
ABSTRAK
Penelitian ini bertujuan untuk mengetahui pengaruh kompensasi, kepemimpinan dan lingkungan kerja terhadap kepuasan kerja pada PT. JNE Express. Sampel yang digunakan dalam penelitian ini adalah karyawan PT. JNE Expressdengan jumlah sampel sebanyak 100 responden. Berdasarkan hasil uji hipotesis yang dilakukan dengan menggunakan Uji F menunjukkan bahwa secara simultan variabel kompensasi, kepemimpinan dan lingkungan kerja berpengaruh positif dan signifikan terhadap kepuasan kerja. Sedangkan hasil uji hipotesis dengan menggunakan Uji $t$ menunjukkan bahwa variabel kompensasi, kepemimpinan dan lingkungan kerja berpengaruh positif dan signifikan terhadap kepuasan kerja. Besarnya persentase sumbangan pengaruh variabel kompensasi, kepemimpinan dan lingkungan kerja terhadap kepuasan kerja pada PT. JNE Express adalah sebesar 89,2\%, sisanya 10,8\% dipegaruhi oleh variabel lain yang tidak dimasukkan dalam penelitian ini.
\end{abstract}

\section{Kata Kunci $\quad$ :Kompensasi, Kepemimpinan,Lingkungan Kerja, Kepuasan Kerja.}

\section{PENDAHULUAN}

Sumber daya manusia adalah salah satu asset di perusahaan yang berharga dan merupakan roda penggerak yang sangat penting untuk memperoleh kinerja yang baik, dengan kata lain sumber daya manusia yang baik dan kompeten di dalam suatu perusahaan, maka perusahaan tersebut akan mengalami ketertinggalan dengan perusahan lain. Manajemen sumber daya manusia sebagai suatu bidang khusus mempelajari hubungan dan peranan manusia dalam suatu organisasi. Unsur dalam manajemen adalah tenaga kerja pada suatu organisasi. Sehingga dalam manajemen SDM faktor yang diperhatikan adalah manusianya itu sendiri. Sumber daya manusia yang dimaksud dalam perusahaan adalah karyawan.

Kepuasan kerja merupakan perasaan senang atau senang pekerja dalam memandang dan menjalankan pekerjaannya (Sutrisno, 2013). Apabila seseorang senang terhadap pekerjannya, maka orang tersebut puas terhadap pekerjaannya, Robbins (2008) menyatakan bahwa kepuasan kerja adalah sikap umum terhadap pekerjaan seseorang. Yang menunjukkan perbedaan antara jumlah penghargaan yang diterima pekerja dan jumlah yang mereka yakini seharusnya mereka terima. Mangkunegara (2017) menyatakan bahwa kepuasan kerja adalahsuatu perasaan yang menyokong diri karyawan yang berhubungan dengan pekerjaannya maupun dengan kondisi dirinya.

PT. JNE Express termasuk salah satu perusahaan yang berkompetisi dalam bidang jasa titipan kilat. Bisnis yang terkait dengan kepuasan pelanggan ini harus mampu berkompetisi dengan perusahaan jasa yang lain untuk menumbuh kembangkan bisnisnya. Pelayanan adalah kunci utama untuk menarik pelanggan dalam bisnis jasa. Kepuasan kerja yang dirasakan karyawan PT. JNE Express masih kurang. Hal ini disebabkan oleh faktor pekerjaan seperti kondisi kerja yang terbilang yang monoton dengan rutinitas pekerjaan yang sama dan waktu yang cukup lama, menyebbabkan para karyawan bosan dan merasa kurang puas atas pekerjaan itu sendiri. Selain itu, karyawan sering memperlambat pengiriman kepada penerima sehingga menyebabkan penerima kurang puas hal ini disebabkan karena kurangnya pengawasan yang ada pada perusahaan.

Kompensasi menurut Hasibuan (2012) dapat diartikan sebagai pendapatan yang berbentuk uang, barang langsung atau tidak langsung yang diterima karyawan sebagai imbalan atas jasa yang diberikan kepada perusahaan. Kompensasi berbentuk uang, artinya gaji dibayar 
dengan sejumlah uang kartal kepada karyawan yang bersangkutan. Kompensasi berbentuk barang, artinya digaji dibayar dengan barang. Misalnya gaji dibayar $10 \%$ dari produksi yang dihasilkan. Kompensasi merupaka yang berkaitan dengan imbalan-imbalan financial (financial reward) yang di terima oleh orang-orang melalui hubungan kepegawaian mereka dengan sebuah organisasi. Pada umumnya bentuk kompensasi berupa financial karena pengeluaran moneter yang dilakukan oleh organisasi. Kompensasi bisa langsung diberikan kepada karyawan, ataupun tidak langsung, dimana karyawan menerima kompensasi dalam bentuk non moneter.

Kompensasi yang PT. JNE Express berikan berupa penghargaan dan Insentif yang dilakukan. Tetapi fenomena yang terjadi, kompensasi yang karyawan terima masih belum dikatakan maksimal. Hal ini dilihat dari masih banyaknya keluhan-keluhan dari pelanggan terkait keterlambatan pengiriman dan penerimaan barang yang dilakukan oleh perusahaan tersebut.

Menurut Chris Rowley and Keith Jackson (2012) kepemimpinan adalah sebuah hubungan yang saling mempengaruhi diantara pemimpin dan pengikut yang menginginkan perubahan nyata dan mencerminkan tujuan bersamanya. Dalam upaya melaksanakan kepemimpinan yang efektif, selain memiliki kemampuan dan keterampilan dalam kepemimpinan, seorang pemimpin sebaiknya menentukan gaya kepemimpinan yang tepat sesuai dengan situasi dan kondisi anggota kelompok.

Banyak perusahaan dihadapkan pada kinerja (Performance) yang bekerja tidak sesuai dengan standar kerja yang sudah ditentukan untuk menunjang tercapainya tujuan dan sasaran perusahaan secara efektif. Tidak terkecuali di PT. JNE Express juga mengalami hal yang serupa. Kemungkinan yang menjadi penyebab adalah kepemimpinan yang tidak mendukung kearah pencapaian tingkat produktifitas kerja yang optimal. Disisi lain, kepemimpinan tersebut merupakan faktor dalam mencapai prestasi dan produktifitas yang tinggi. Sehubung dengan itu, dengan melalui manajemen yang besar setidaknya akan memudahkan pengelolaan kinerja karyawan tersebut.

Lingkungan kerja adalah faktor-faktor dan kekuatan yang berada didalam maupun luar organisasi namun mempengaruhi kinerja (Robbin dan Coulter 2010:79). Pengertian lainnya lingkungan kerja adalah segala sesuatu yang ada disekitar para pekerja dan yang dapat mempengaruhi dirinya dalam menjalankan tugas-tugas yang dibebankan (Suntoyo, 2012:43). Perhatian terhadap lingkungan manajemen penting karena tiap elemen lingkungan mempengaruhi baik langsung dan tidak langsung terhadap kegiatan-kegiatan manajerial. Tetapi, tidak semua lingkungan sama dan tidak tidak semua organisasi memiliki lingkungan yang sama, sementara organisasi tidak mempunyai informasi yang cukup tentang keadaan lingkungannya.

Lingkngan kerja yang berada di PT. JNE Express masih kurang maksimal untuk suatu kualitas pelayana dan kepuasan kerjanya karena didalam lingkungan kerja tersebut masih ada yang tergesa-gesa dalam melakukan pelayanan dan memindahkan barang dengan sendirinya yang tidak dilakukan dengan tim (team).

Penelitian yang dilakukan oleh Hendro Tamali (2019) menyatakan bahwa lingkungan kerja berpengaruh terhadap kepuasan kerja. Sedangkan penelitian Wongkar (2018) menyatakan lingkungan kerja tidak berpengaruh terhadap kepuasan kerja.

Penelitian yang dilakukan oleh Aprilia Christy Mawei (2014) menyatakan bahwa kompensasi tidak berpengaruh terhadap kepuasan kerja. Sedangkan penelitian yang dilakukan Hadinata (2014) menyatakan kompensasi berpengaruh terhadap kepuasan kerja.

Penelitian yang dilakukan oleh Dede Siti Rohmah (2012) menyatakan bahwa kepemimpian berpengaruh secara positif terhadap kepuasan kerja. Sedangkan penelitian yang dilakukan oleh Hidayat (2013) menyatakan bahwa kepemimpinan tidak berpengaruh langsung terhadap kepuasan kerja.

Berdasarkan latar belakang tersebut di atas, peneliti mengambil penelitian dengan judul :

\section{PENGARUH KOMPENSASI, KEPEMIMPIAN, DAN LINGKUNGAN KERJA TERHADAPKEPUASAN KERJA KARYAWAN PADA PT. JNE EXPRESS}




\section{Desain Penelitian}

Desain penelitian yang digunakan adalah penelitian kasual (Casual Research) yang merupakan metode penelitian untuk mengidentifikasi hubungan sebab-akibat (Jusuf Soerwadji, 2012). Penelitian kasual digunakan untuk mengetahui pengaruh antara satu atau lebih variable bebas (Independent Variable) terhadap variable terikat (Dependent Variable).

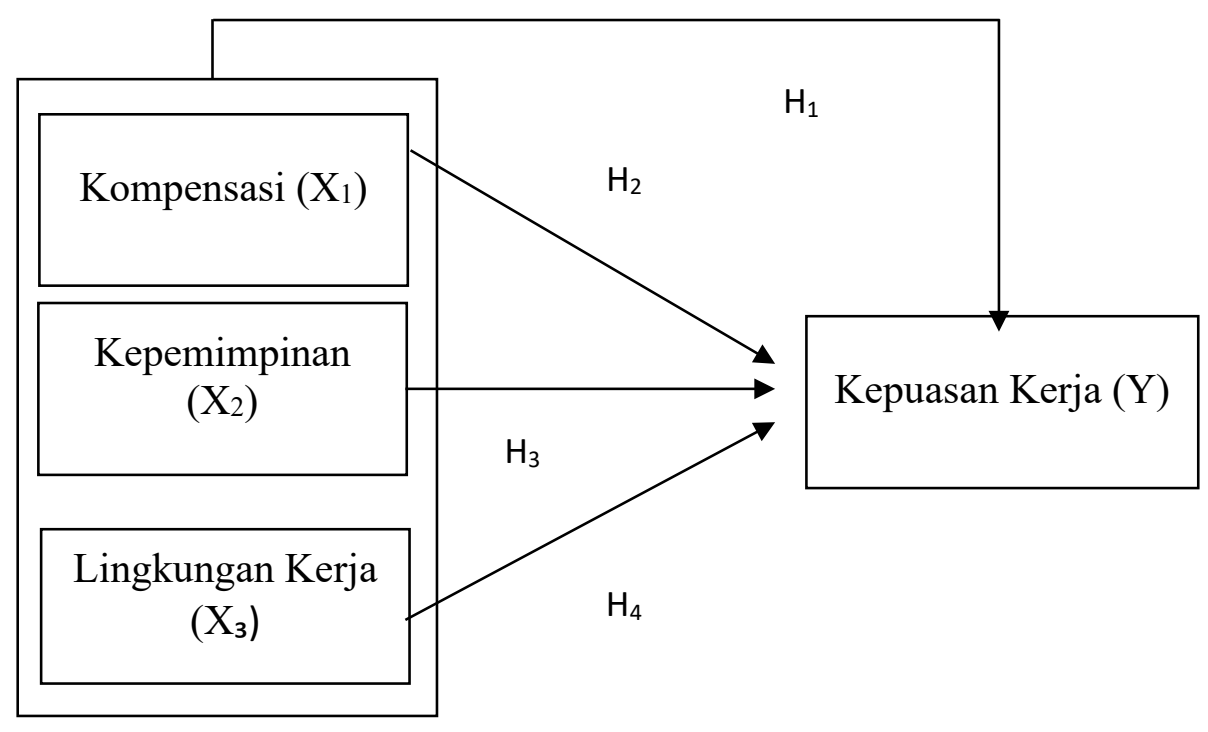

\section{Kerangka Pemikiran Teoritis}

Berdasarkan kerangka pemikiran yang telah diuraikan diatas, maka dapat diangkat hipotesis penelitian sebagai berikut:

$\mathrm{H}_{1}$ : Kompensasi, Kepemimpinan dan Lingkungan Kerja Secara Simultan Berpengaruh Terhadap Kepuasan Kerja

$\mathrm{H}_{2}$ : Kompensasi Berpengaruh Terhadap Kepuasan Kerja

$\mathrm{H}_{3}$ : Kepemimpinan Berpengaruh Terhadap Kepuasan Kerja

$\mathrm{H}_{4}$ : $\quad$ Lingkungan Kerja Berpengaruh Terhadap Kepuasan Kerja

\section{LANDASAN TEORI}

\section{Kepuasan Kerja}

Edy Sutrisno (2016) mengemukakan bahwa kepuasan kerja adalah keadaan emosional menyenangkan atau tidak menyenangkan bagi para karyawan memandang pekerjaan mereka.

Malayu S.P, Hasibuan (2014:202) menyatakan bahwa kepuasan kerja adalah sikap emosional yang menyenangkan dan mencintai pekerjaannya. Sikap in dicerminkan oleh moral kerja, kedisiplinan dan prestasi kerja.

Jadi dapat disimpulkan, bahwa kepuasan kerja tersebut dapat dirasakan oleh pegawai sendiri bagaimana situasi dan kondisi disuatu pekerjaannya dan pegawai tersebut akan mendapatkan hasil yang baik ketika dia melakukan pekerjaan dengan baik atau berprestasi ditempat perusahaan tersebut.

\section{Kompensasi}


Thomas H.Stone (2011)kompensasi adalah semua pendapat yang berbentuk uang barang langsung mau pun barang tidak langsung yang diterima karyawan sebagai imbalan atau jasa yang diberikan pada lembaga. Serta kompensasi tambahan finansial atau non finansial yang diberikan berdasarkan kebijaksanaan lembaga terhadap semua karyawan dan usaha meningkatkan kesejahteraan mereka seperti tunjangan hari raya dan uang pensiun.

\section{Kepemimpinan}

Kepemimpinan memegang peran yang penting karena pemimpin itulah yang akan menggerakan dan mengarahkan organisasi dalam mencapai tujuan dan sekaligus merupakan tugas yang tidak mudah. Ada bermacam-macam pengertian mengenai kepemimpinan yang diberikan oleh para ahli. Namun pada intinya, kepemimpinan suatu proses kegiatan seorang untuk menggerakan orang lain dengan pemimpin suatu proses kegiatan seseorang untuk menggerakan orang lain dengan memimpin, membimbing, mempengaruhi orang lain, untuk melakukan sesuatu agar dicapai hasil yang di harapkan (Sutrisno, 2016).

\section{Lingkungan Kerja}

Menurut Kasmir (2016:192) lingkungan kerja merupakan suasana atau kondisi disekitar lokasi tempat bekerja. Definisi diatas menjelaskan lingkungan kerja dapat berupa ruangan, layout, saran dan prasarana serta hubungan kerja dengan sesame rekan kerja. Jika lingkungan kerja dapat membuat suasana nyaman dan memberikan ketenangan maka akan membuat suasana kerja menjadi kondusif, sehingga dapat meningkatkan hasil kerja seseorang menjadi lebih baik, karena lingkungan tanpa gangguang.

\section{METODOLOGI PENELITIAN}

Metode penelitian menyangkut prosedur dan cara melakukan pengolahan data yang diperlukan untuk menjawab atau memecahkan masalah penelitian termasuk menguji hipotesis. Untuk mengungkap permasalahan dalam penelitian ini, maka peneliti menggunakan metode kausal.Metode kausal merupakan metode yang digunakan untuk mengetahui hubungan antara dua variabel atau lebih.Bentuk metode yang digunakan dalam penelitian ini adalah bentuk kausal (hubungan sebab akibat).

Tabel

\section{Ringkasan Operasional Variabel}

\begin{tabular}{|c|c|c|c|c|c|}
\hline No. & Variabel & Dimensi & Indikator & Butir & Skala \\
\hline \multirow[t]{10}{*}{1} & \multirow{10}{*}{$\begin{array}{c}\text { Kepuasan Kerja } \\
\text { Menurut Robbins and } \\
\text { Judge dalam } \\
\text { Puspitawati (2013:18) }\end{array}$} & \multirow{4}{*}{$\begin{array}{ll}\text { a. } & \text { Pekerjaan itu } \\
\text { sendiri }\end{array}$} & Tugas yang menarik & $1,2,3$ & \multirow{10}{*}{$\begin{array}{l}\text { Likert } \\
(1-5)\end{array}$} \\
\hline & & & Kesempatan untuk belajar & $4,5,6$ & \\
\hline & & & $\begin{array}{l}\text { Kesempatan untuk menerima } \\
\text { tanggungjawab }\end{array}$ & $7,8,9$ & \\
\hline & & & Kemajuan untuk karyawan & $10,11,12$ & \\
\hline & & \multirow{3}{*}{$\begin{array}{ll}\text { b. } & \text { Pengawan } \\
& \text { (Supervisi) }\end{array}$} & Kepedulian terhadap karyawan & $13,14,15$ & \\
\hline & & & Bantuan teknis & $16,17,18$ & \\
\hline & & & Dukungan perilaku & $19,20,21$ & \\
\hline & & \multirow[t]{3}{*}{ c. Rekan Kerja } & Rekan kerja yang kooperatif & $22,23,24$ & \\
\hline & & & $\begin{array}{ll}\text { Rekan kerja } & \text { yang } \\
\text { menyenangkan }\end{array}$ & $25,26,27$ & \\
\hline & & & $\begin{array}{l}\text { Rekan kerja yang mendukung } \\
\text { pekerjaan }\end{array}$ & $28,29,30$ & \\
\hline \multirow[t]{4}{*}{2} & \multirow{4}{*}{$\begin{array}{l}\text { Kompensasi Menurut } \\
\text { Handoko (2012:56) }\end{array}$} & \multirow{3}{*}{$\begin{array}{l}\text { a. Kompensasi } \\
\text { Langsung }\end{array}$} & Upah dan Gaji & $1,2,3$ & \multirow{4}{*}{$\begin{array}{l}\text { Likert } \\
(1-5)\end{array}$} \\
\hline & & & Insentif & $4,5,6$ & \\
\hline & & & Bonus & $7,8,9$ & \\
\hline & & $\begin{array}{l}\text { b. Kompensasi } \\
\text { Tidak Langsung }\end{array}$ & $\begin{array}{lll}\begin{array}{l}\text { Pembayaran } \\
\text { bekerja }\end{array} & \text { untuk waktu } \\
\end{array}$ & $10,11,12$ & \\
\hline
\end{tabular}




\begin{tabular}{|c|c|c|c|c|c|}
\hline No. & Variabel & Dimensi & Indikator & Butir & Skala \\
\hline & & & Asuransi & $13,14,15$ & \\
\hline & & & Program Pelayanan & $16,17,18$ & \\
\hline \multirow[t]{9}{*}{3} & \multirow{9}{*}{$\begin{array}{l}\text { Kepemimpinan } \\
\text { Menurut Thoba } \\
\quad(2010: 52)\end{array}$} & \multirow[t]{3}{*}{ a. Inovator } & Kemampuan Inovasi & $1,2,3$ & \multirow{9}{*}{$\begin{array}{c}\text { Likert } \\
(1-5)\end{array}$} \\
\hline & & & Kemampuan Konseptual & $4,5,6$ & \\
\hline & & & Kemampuan Penyampaian & $7,8,9$ & \\
\hline & & \multirow[t]{3}{*}{ b. Komunikator } & $\begin{array}{l}\text { Kemampuan menyampaikan } \\
\text { maksud dan tujuan komunikasi }\end{array}$ & $10,11,12$ & \\
\hline & & & $\begin{array}{l}\text { Kemampuan dalam memahami, } \\
\text { mengerti, dan mengambil } \\
\text { intisari pembicaraan }\end{array}$ & $13,14,15$ & \\
\hline & & & $\begin{array}{l}\text { Kemampuan mengambil } \\
\text { keputusan }\end{array}$ & $16,17,18$ & \\
\hline & & \multirow[t]{3}{*}{ c. Motivator } & Kemampuan memotivasi & $19,20,21$ & \\
\hline & & & $\begin{array}{l}\text { Kemampuan memberikan } \\
\text { bimbingan dan arahan }\end{array}$ & $22,23,24$ & \\
\hline & & & $\begin{array}{ll}\text { Kemampuan } & \text { menyikapi } \\
\text { permasalahan } & \\
\end{array}$ & $25,26,27$ & \\
\hline \multirow[t]{9}{*}{4} & \multirow[t]{9}{*}{ Lingkungan Kerja } & \multirow{3}{*}{$\begin{array}{l}\text { a. Pertukaran } \\
\text { Udara }\end{array}$} & Suhu udara & $1,2,3$ & \multirow{9}{*}{$\begin{array}{l}\text { Likert } \\
(1-5)\end{array}$} \\
\hline & & & Alat pengatur suhu udara & $4,5,6$ & \\
\hline & & & Fungsi ventilasi & $7,8,9$ & \\
\hline & & \multirow[t]{3}{*}{ b. Keamanan } & Jaminan kesehatan karyawan & $10,11,12$ & \\
\hline & & & Jaminan keselamatan karyawan & $13,14,15$ & \\
\hline & & & Ancaman dari luar & $16,17,18$ & \\
\hline & & \multirow[t]{3}{*}{ c. Kebisingan } & Konstruksi ruang kerja & $19,20,21$ & \\
\hline & & & Alat peredam suara & $22,23,24$ & \\
\hline & & & Pengaruh kebisingan & $25,26,27$ & \\
\hline
\end{tabular}

Sumber : data diolah 2020

\section{Populasi dan Teknik Penarikan Sampel}

Menurut Sugiyono (2016:115) menyatakan populasi adalah wilayah generalisasi yang terdiri atas objek/subjek yang mempunyai kualitas dan karakteristik tertentu yang ditetapkan oleh peneliti untuk dipelajari dan kemudian ditarik kesimpulan. Jadi dalam penelitian ini populasi adalah jumlah seluruh karyawan di PT. JNE Express sebanyak 74 karyawan

Menurut Sugiyono (2016:116), sampel adalah bagian dari jumlah dan karakteristik yang dimiliki oleh populasi tersebut. Namun bila populasi kurang dari 100 maka lebih baik keseluruhan populasi dijadikan sampel agar data yang di peroleh dapat lebih dipertanggungjawabkan. Penentuan jumlah sampel dalam penelitian ini dapat menggunakan rumus teori Roscoe. Teori Roscoe mengatakan bila dalam penelitian akan melakukan analisis dengan multivariate (kolerasi atau regresi ganda), maka jumlah anggota sampel minimal 10 kali dari jumlah variabel yang diteliti (Sugiyono, 2010:130). Jadi karena penelitian ini terdiri dari 4 variabel, maka jumlah sampel minimal adalah $4 \times 10=40$ responden. Dalam penelitian ini jumlah sampel yang digunakan adalah menggunakan keseluruhan responden dalam populasi yaitu sebanyak 74 responden.

\section{HASIL PENELITIAN}

Jumlah kuesioner yang dikirim dan kuesioner yang kembali untuk masing-masing Kantor PT. JNE EXPRESS Kuesioner yang disebar 115, Kuesioner yang kembali 109, Kuesioner yang tidak lengkap/Kosong 9, Kuesioner yang layak dianalisis 100.

\section{Uji Reliabilitas}


Nilai Cronbach's Alpha yang biasanya digunakan yaitu: lebih besar dari 0,7 atau >0,7. Semakin besar nilai Cronbach's Alpha, maka semakin baik pula pengukuran variabel tersebut.

Tabel

\section{Uji Reliabilitas}

\begin{tabular}{|l|c|c|c|}
\hline \multicolumn{1}{|c|}{ Variabel } & Cronbach's Alpha & Batas Nilai & Keterangan \\
\hline Kepuasan Kerja &, 993 & 0,70 & Reliabel \\
\hline Kompensasi &, 978 & 0,70 & Reliabel \\
\hline Kepemimpinan &, 991 & 0,70 & Reliabel \\
\hline Lingkungan Kerja &, 986 & 0,70 & Reliabel \\
\hline
\end{tabular}

Sumber : Output Spss Versi 22

Berdasarkan hasil uji reliabilitas di atas dapat disimpulkan bahwa pernyataan dalam kuisioner ini reliable karena mempunyai nilai Cronbach's Alpha lebih besar dari 0,7 artinya Otonomi, Ambiguitas Peran, Profesionalisme, dan Kinerja Auditor bersifat reliabel atau dapat dipercaya.

\section{Uji Normalitas} berikut :

Hasil uji normalitas dengan menggunakan Uji Kolmogorof Smirnov adalah sebagai

Tabel

Uji Normalitas

Tests of Normality

\begin{tabular}{|l|r|r|r|r|r|r|}
\hline & \multicolumn{3}{|c|}{ Kolmogorov-Smirnov $^{\mathrm{a}}$} & \multicolumn{3}{c|}{ Shapiro-Wilk } \\
\cline { 2 - 7 } & Statistic & df & \multicolumn{1}{c|}{ Sig. } & \multicolumn{1}{c|}{ Statistic } & \multicolumn{1}{c|}{ Df } & Sig. \\
\hline KEPUASAN KERJA &, 081 & 100 &, 104 &, 978 & 100 &, 094 \\
KOMPENSASI &, 079 & 100 &, 131 &, 956 & 100 &, 002 \\
KEPEMIMPINAN &, 066 & 100 &, $200^{*}$ &, 978 & 100 &, 087 \\
LINGKUNGAN KERJA &, 077 & 100 &, 153 &, 967 & 100 &, 014 \\
\hline
\end{tabular}

*. This is a lower bound of the true significance.

a. Lilliefors Significance Correction

Berdasarkan hasil uji normalitas dengan One Sample Kolmogorov dapat diketahui bahwa data dalam penelitian terdistribusi normal. Hal ini dapat dilihat dari Sig $>\alpha=0,05$ berarti dapat disimpulkan bahwa data tersebut berdistribusi normal dan populasi berdistribusi normal.

\section{Uji Multikolinieritas}

Uji Multikoliniearitas bertujuan untuk menguji apakah model regresi ditemukan adanya korelasi antar variabel bebas (independent).

Tabel

Uji Multikoliniearitas

\begin{tabular}{|ll|r|r|}
\hline \multirow{2}{*}{ Model } & \multicolumn{2}{|c|}{ Collinearity Statistics } \\
\cline { 3 - 4 } 1 & (Constant) & \multicolumn{1}{|c|}{ Tolerance } & \multicolumn{1}{c|}{ VIF } \\
& KOMPENSASI &, 183 & 5,471 \\
& KEPEMIMPINAN &, 231 & 4,322 \\
& LINGKUNGAN KERJA &, 159 & 6,298 \\
\hline
\end{tabular}


Berdasarkan Tabel diketahui bahwa nilaiTolerance dan Nilai VIF ketiga variabel pada penelitian ini nilai Tolerance $>0,1$ dan Nilai VIF $<$ dari 10, maka dapat disimpulakan bahwa tidak terjadi gejala Multikolonearitas antar variabel bebas.

\section{Uji Heterokedastisitas}

Untuk menguji hal ini digunakan Scatterplot, dimana sumbu $\mathrm{X}$ adalah nilai-nilai prediksi, Selain itu uji heterokedastisitas dilakukan dengan uji glejser, dengan melihat nilai Sig lebih besar dari 0,05 maka tidak terjadi heterokedastisitas, maka berikut hasil ujinya :

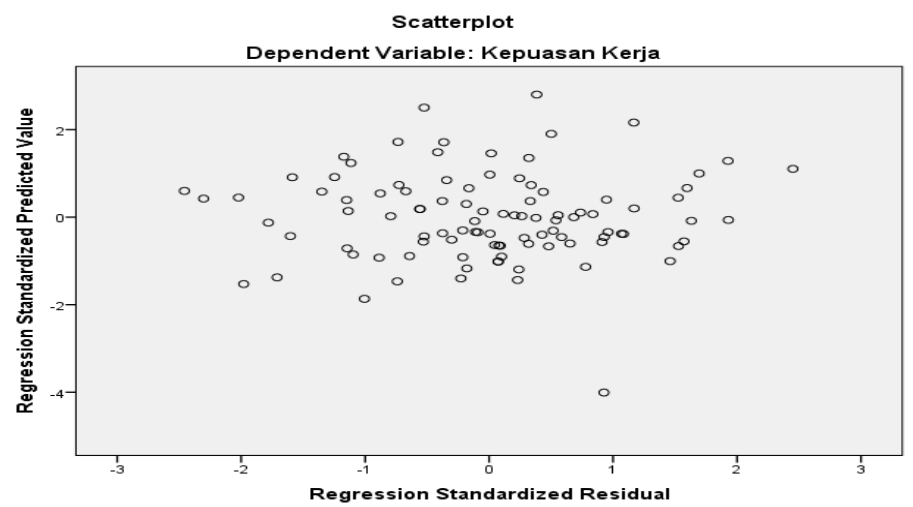

Sumber : Output Spss Versi 22

\section{Gambar}

\section{Uji Heterokedastisitas}

Uji heterokedastisitas pada Gambar menggunakan grafik scaterplot menunjukkan bahwa titik membentuk pola tidak jelas, dan titik-titik menyebar diatas dan dibawah menyebar secara acak, dibawah serta diatas angka 0 pada sumbu Y, dan tidak mempunyai pola yang teratur. Hal ini dapat disimpulkan bahwa tidak terjadi heteroskedastisitas pada model regresi, sehingga model refresi layak dipakai untuk memprediksi dan peneliti dapat melanjutkan pengujian selanjutnya.

\section{Uji Auto Korelasi}

Uji autokorelasi bertujuan menguji apakah dalam model regresi linear ada korelasi antara kesalahan pengganggu pada periode $\mathrm{t}$ dengan kesalahan pengganggu pada periode $\mathrm{t}-1$ (sebelumnya). Model regresi yang baik adalah regresi yang bebas dari autokorelasi. Metode pengujian yang sering digunakan adalah dengan uji Durbin-Watson (Uji DW).

\section{Tabel}

\section{Uji Auto Korelasi}

\begin{tabular}{|l|r|r|r|r|r|}
\hline Model & \multicolumn{1}{|c|}{$\mathrm{R}$} & R Square & $\begin{array}{c}\text { Adjusted R } \\
\text { Square }\end{array}$ & $\begin{array}{c}\text { Std. Error of the } \\
\text { Estimate }\end{array}$ & Durbin-Watson \\
\hline 1 &, $946^{a}$ &, 895 &, 892 & 2,82977 & 1,795 \\
\hline
\end{tabular}

Sumber : Output Spss Versi 22

Berdasarkan hasil tabel diatas dengan uji Durbin Watson menunjukkan nilai sebesar 1,795 yang artinya bahwa $\mathrm{dU}<\mathrm{d}<4$-dU maka diindikasikan tidak ada autokorelasi. 


\section{Analisis Korelasi}

Untuk menganalisis korelasi antara variable Kompensasi, Kepemimpinan, dan Lingkungan Kerja Terhadap Kepuasan Kerja.

\section{Tabel}

Uji Analisis Korelasi

\begin{tabular}{|c|c|c|c|c|c|}
\hline & & $\begin{array}{l}\text { KEPUASAN } \\
\text { KERJA }\end{array}$ & $\begin{array}{c}\text { KOMPENSA } \\
\text { SI }\end{array}$ & $\begin{array}{c}\text { KEPEMIMPINA } \\
\mathrm{N}\end{array}$ & $\begin{array}{l}\text { LINGKUNGA } \\
\text { N KERJA }\end{array}$ \\
\hline \multirow[t]{3}{*}{ KEPUASAN KERJA } & Pearson Correlation & 1 &, $878^{* *}$ &, $919^{* *}$ &, $898^{* *}$ \\
\hline & Sig. (2-tailed) & &, 000 &, 000 &, 000 \\
\hline & $\mathrm{N}$ & 100 & 100 & 100 & 100 \\
\hline \multirow[t]{3}{*}{ KOMPENSASI } & Pearson Correlation &, $878^{* *}$ & 1 &, $840^{* *}$ &, $894^{* *}$ \\
\hline & Sig. (2-tailed) &, 000 & &, 000 &, 000 \\
\hline & $\mathrm{N}$ & 100 & 100 & 100 & 100 \\
\hline \multirow[t]{3}{*}{ KEPEMIMPINAN } & Pearson Correlation & ,919** &, $840^{* *}$ & 1 &, $863^{* *}$ \\
\hline & Sig. (2-tailed) &, 000 &, 000 & &, 000 \\
\hline & $\mathrm{N}$ & 100 & 100 & 100 & 100 \\
\hline \multirow{3}{*}{$\begin{array}{l}\text { LINGKUNGAN } \\
\text { KERJA }\end{array}$} & Pearson Correlation &, $898^{* *}$ &, $894^{* *}$ &, $863^{* *}$ & 1 \\
\hline & Sig. (2-tailed) &, 000 &, 000 &, 000 & \\
\hline & $\mathrm{N}$ & 100 & 100 & 100 & 100 \\
\hline
\end{tabular}

**. Correlation is significant at the 0.01 level (2-tailed).

Sumber: Output Spss Versi 22

Berdasarkan tabel diatas, selanjutnya dapat dilakukan interprestasi hubungan masingmasing variabel sebagai berikut :

1. Koefisien korelasi antara Kompensasi $\left(\mathrm{X}_{1}\right)$ dengan Kepuasan Kerja $(\mathrm{Y})$ sebesar 0,878 mendekati 0 dengan signifikansi $0,000<0,05$ menunjukan Kompensasi memiliki korelasi yangKuat terhadap Kepuasan Kerja

2. Koefisien korelasi antara Lingkungan Kerja $\left(\mathrm{X}_{2}\right)$ dengan Kepuasan Kerja (Y) sebesar 0,919 mendekati 0 dengan signifikansi $0,000<0,05$ menunjukan Lingkungan Kerja memiliki korelasi yang Kuat terhadap Kepuasan Kerja

3. Koefisien korelasi antara Kepemimpinan $\left(\mathrm{X}_{3}\right)$ dengan Kepuasan Kerja (Y) sebesar 0,898 mendekati 0 dengan signifikansi $0,000<0,05$ menunjukkan Kepemimpinan memiliki korelasi Kuat terhadap Kepuasan Kerja

\section{Analisis Regresi Linier Berganda}

Dalam Pengolahan data dengan menggunakan metode regresi linear berganda, dilakukan beberapa tahapan untuk mencari hubungan variable independen dan variable dependen, yaitu dengan cara menganalisis Kompensasi (X1), Kepemimpinan (X2), dan Lingkungan Kerja (X3), terhadap Kepuasan Kerja (Y).

\section{Tabel}

\section{Uji Analisis Regresi Linier Berganda}

\begin{tabular}{|c|c|c|c|c|c|c|}
\hline \multirow{2}{*}{\multicolumn{2}{|c|}{ Model }} & \multicolumn{2}{|c|}{ Unstandardized Coefficients } & \multirow{2}{*}{$\begin{array}{l}\text { Standardized } \\
\text { Coefficients } \\
\text { Beta }\end{array}$} & \multirow[b]{2}{*}{$\mathrm{T}$} & \multirow[b]{2}{*}{ Sig. } \\
\hline & & $\mathrm{B}$ & Std. Error & & & \\
\hline \multirow[t]{4}{*}{1} & (Constant) &,- 051 & 3,447 & &,- 015 & ,988 \\
\hline & KOMPENSASI & ,289 &, 112 & 200 & 2,588 & 011 \\
\hline & KEPEMIMPINAN &, 512 & 069 &, 511 & 7,450 &, 000 \\
\hline & LINGKUNGAN KERJA & 279 & ,083 & ,278 & 3,362 & ,001 \\
\hline
\end{tabular}


Sumber : Output Spss Versi 22

Berdasarkan tabel maka diperoleh bentuk persamaan model regresi linear berganda sebagai berikut:

$$
\begin{aligned}
& Y=\alpha+\beta_{1} X_{1}+\beta_{2} X_{2}+\beta_{3} X_{3}+e \\
& Y=-0,051+0,289 X_{1}+0,512 X_{2}+0,279 X_{3}+e
\end{aligned}
$$

Model tersebut dapat di interpretasikan sebagai berikut :

a. Nilai a (konstanta) pada hasil pengujian di atas adalah sebesar -0,051 yang berarti bahwa jika variabel independen (Kompensasi, Kepemimpinan, dan Lingkungan Kerja) konstan, maka Kepuasan Kerja akan mengalami penurunan sebesar -0,051. Nilai konstanta sebesar -0,051 menunujukkan nilai murni dari variabel Kepuasan Kerja (dependen) tanpa di pengaruhi variabel independen.

b. Koefisien Kompensasi adalah sebesar 0,289 dimana angka ini menunjukkan bahwa setiap peningkatan variabel Kompensasi sebesar satu satuan, maka akan meningkatkan Kepuasan Kerja sebesar 0,289. Koefisien bernilai positif artinya terdapat hubungan positif antara Kompensasi. Semakin meningkat Kompensasi maka akan meningkatkan Kepuasan Kerja.

c. Koefisien Kepemimpinan adalah sebesar 0,512 dimana angka ini menunjukkan bahwa setiap penurunan variabel Kepemimpinan sebesar satu satuan, maka akan meningkatkan Kepuasan Kerja sebesar 0,512. Koefisien bernilai positif artinya terdapat hubungan positif Kepemimpinan. Semakin meningkatkan Kepemimpinan, maka akan meningkatkan Kepuasan Kerja.

d. Koefisien Lingkungan Kerja adalah sebesar 0,279 dimana angka ini menunjukkan bahwa setiap peningkatan variabel Lingkungan Kerja sebesar satu satuan, maka akan meningkatkan Kepuasan Kerja sebesar 0,279. Koefisien bernilai positif artinya terdapat hubungan positif antara Lingkungan Kerja. Semakin meningkat Lingkungan Kerja, maka akan meningkatkan Kepuasan Kerja

\section{Uji Simultan (Uji f)}

Uji F menunjukkan semua variabel independen mempunyai pengaruh secara bersamasama terhadap variabel dependen.

\section{Tabel}

\section{Hasil Uji F Simultan}

ANOVA $^{\mathrm{a}}$

\begin{tabular}{|ll|r|r|r|r|r|}
\hline Model & & Sum of Squares & Df & Mean Square & F & Sig. \\
\hline 1 & Regression & 6582,912 & 3 & 2194,304 & 274,028 &, $000^{\mathrm{b}}$ \\
& Residual & 768,728 & 96 & 8,008 & & \\
& Total & 7351,640 & 99 & & & \\
\hline
\end{tabular}

a. Dependent Variable: KEPUASAN KERJA

b. Predictors: (Constant), LINGKUNGAN KERJA, KEPEMIMPINAN, KOMPENSASI

Sumber : Output SPSS versi 22

Pada Tabel di atas menunjukkan hasil uji F dengan nilai F Hitung sebesar $274.028>$ Nilai F tabel 2.70 dan nilai signifikansi sebesar $0,000<005$ maka Ho ditolak dan Ha diterima. Artinya variabel independen (Kompensasi, Kepemimpinan, dan Lingkungan Kerja) secara simultan berpengaruh positif dan signifikan terhadap variabel dependen (Kepuasan Kerja).

\section{Uji Parsial ( Uji t )}


Uji $\mathrm{t}$ digunakan untuk mengetahui apakah dalam model regresi variabel bebas (independent variable) secara parsial (individual) berpengaruh terhadap variabel terikat (dependen variable).

Tabel

Hasil Uji Signifikansi Parsial (Uji t)

\begin{tabular}{|c|c|c|c|c|c|c|}
\hline \multirow{2}{*}{\multicolumn{2}{|c|}{ Model }} & \multicolumn{2}{|c|}{ Unstandardized Coefficients } & $\begin{array}{l}\text { Standardized } \\
\text { Coefficients }\end{array}$ & \multirow[b]{2}{*}{$\mathrm{T}$} & \multirow[b]{2}{*}{ Sig. } \\
\hline & & $\mathrm{B}$ & Std. Error & Beta & & \\
\hline \multirow[t]{4}{*}{1} & (Constant) &,- 051 & 3,447 & &,- 015 & ,988 \\
\hline & KOMPENSASI & ,289 &, 112 & ,200 & 2,588 & 011 \\
\hline & KEPEMIMPINAN & ,512 & ,069 &, 511 & 7,450 &, 000 \\
\hline & LINGKUNGAN KERJA & ,279 &, 083 & ,278 & 3,362 &, 001 \\
\hline
\end{tabular}

Sumber : Output Spss Versi 22

a. Variabel Kompensasi $\left(\mathrm{X}_{1}\right)$ nilai thitung 2,588> t tabel 1,984 dan nilai signifikansi $(0,011<$ 0,05) maka Ho ditolak dan Ha diterima, yang artinya Kompensasi berpengaruh signifikan terhadap Kepuasan Kerja.

b. Variabel Kepemimpinan $\left(\mathrm{X}_{2}\right)$ nilai t hitung 7,450> t tabel 1,984 dan nilai signifikansi $(0,000<0,05)$ maka Ho ditolak dan Ha diterima, yang artinya Kepemimpinan berpengaruh signifikan terhadap Kepuasan Kerja.

c. Variabel Lingkungan Kerja $\left(\mathrm{X}_{3}\right)$ nilai t hitung 3,362> t tabel 1,984 dan nilai signifikansi $(0,001<0,05)$ maka Ho ditolak dan Ha diterima, yang artinya Lingkungan Kerja berpengaruh signifikan terhadap Kepuasan Kerja.

\section{Koefisien Determinasi}

Koefisien determinasi pada intinya mengukur sebarapa jauh kemampuan model dalam menerangkan variasi variabel dependen.Nilai koefisien determinasi antara 0 dan 1 .Nilai $\mathrm{R}^{2}$ yang kecil berarti kemampuan variabel-variabel independen dalam menjelaskan variasi variabel dependen amat terbatas.

Tabel

Hasil Uji Koefisien Determinasi

\begin{tabular}{|c|c|c|c|c|c|}
\hline Model & $\mathrm{R}$ & R Square & Adjusted R Square & $\begin{array}{c}\text { Std. Error of the } \\
\text { Estimate }\end{array}$ & Durbin-Watson \\
\hline 1 &, $946^{\mathrm{a}}$ & ,895 & ,892 & 2,82977 & 1,795 \\
\hline
\end{tabular}

a. Predictors: (Constant), LINGKUNGAN KERJA, KEPEMIMPINAN, KOMPENSASI

b. Dependent Variable: KEPUASAN KERJA

Sumber : Output SPSS versi 22

Dari Tabel dapat dilihat bahwa nilai Adjusted R Square sebesar 0,892 (89,2\%) artinya menunjukkan bahwa presentase sumbangan pengaruh variabel independen (Kompensasi, Kepemimpinan, dan Lingkungan Kerja) terhadap variabel dependen (Kepuasan Kerja) adalah sebesar $89,2 \%$ sedangkan sisanya sebesar $10,8 \%$ dipengaruhi oleh faktor-faktor lain yang tidak termasuk dalam penelitian ini.

\section{PENUTUP}

\section{Kesimpulan}

Berdasarkan hasil penelitianyang dilakukan untuk menguji pengaruh Kompensasi, Kepemimpinan dan Lingkungan Kerja terhadap Kepuasan Kerja, maka dapat disimpulkan hasil penelitian ini sebagai berikut : 
1. Kompensasi, Kepemimpinan dan Lingkungan Kerja berpengaruh terhadap Kepuasan Kerja karyawan pada Kantor PT. JNE Express.

2. Kompensasi berpengaruh terhadap Kepuasan Kerja karryawan pada Kantor PT. JNE Express.

3. Kepemimpinan berpengaruh terhadap Kepuasan Kerja karryawan pada Kantor PT. JNE Express.

4. Lingkungan Kerja berpengaruh terhadap Kepuasan Kerja karryawan pada Kantor PT. JNE Express.

\section{Saran}

Berdasarkan hasil pembahasan dalam penelitian ini, maka dapat penulis sarankan sebagai berikut :

1. Kompensasi berpengaruh terhadap kepuasan kerja, hal ini berarti kompensasi dalam penelitian ini bukan menjadi salah satu faktor yang mempengaruhi kepuasan kerja. Hal ini dapat dilihat dari hasil pengolahan data kuesioner dimana skor tertinggi ada pada indikator insentif, sedangkan skor terendah ada pada indikator asuransi.Berdasarkan hal tersebut maka perusahaan dalam hal kompensasi kepada karyawan yang berkaitan dengan insentif selama ini sudah bagus dan perlu dipertahankan. Sedangkan kompensasi yang terkait asuransi masih harus dilakukan oleh perusahaan, karena hal ini menunjukkan bahwa selama ini perusahaan perlu memberikan asuransi yang dibutuhkan oleh karyawan, agar karyawan merasa aman dan nyaman dalam bekerja karena karyawan mendapatkan fasilitas asuransi.

2. Skor terendah dalam variabel kepemimpinan adalah kepemimpinan motivator, yaitu pada indikator kemampuan menyikapi permasalahan. Sebaiknya pimpinan perusahaan dalam hal penanganan masalah yang terjadi di perusahaan mampu menangani permasalahan yang ada dengan baik dan mampu menyikapinya dengan bijaksana karena peran pimpinan harus dapat mengayomi karyawannya sebagai bagian dari perusahaan.

3. Skor terendah dalam variabel lingkungan kerja adalah keamanan, yaitu pada indikator jaminan keselamatan karyawan. Sebaiknya perusahaan disamping perlu memperhatikan lingkungan kerja secara fisik juga lingkungan kerja non fisik, yaitu jaminan keselamatan kerja pada para karyawannya. Karena dengan adanya jaminan keselamatan kerja yang diberikan perusahaan akan membuat karyawan merasa tenang dan nyaman dalam bekerja serta merasa mendapat perlindungan dari perusahaan.

\section{DAFTAR PUSTAKA}

Anwar Prabu Mangkunegara, 2017. Manajemen Sumber Daya Manusia Perusahaan. Bandung: Remaja Rosdakarya.

Chris Rowley \& Keith Jackson. 2012. Manajemen Sumber Daya Manusia The Key Concepts, Cetakan Kesatu, PT Rajagrafindo Persada, Jakarta.

Danang, Sunyoto. 2012. Manajemen Sumber Daya Manusia. Jakarta: PT Buku Seru

Handoko, T. Hani. 2012. Manajemen Personalia dan Sumber Daya Manusia. Yogyakarta. BPFE

Ghazali, Imam (2016). Analisis Pengoperasian IBM SPSS. Semarang: Undip.

Soewadji, Jusuf, Pengantar Metodologi Peneletian, Jakarta : Mitra Wacana Media, 2012.

Kasmir, 2016. Manajemen Sumber Daya Manusia (Teori dan Praktik). Depok: Rajagrafindo Persada.

Hasibuan, Malayu Sp. 2012. Manajemen SDM. Edisi Revisi, Cetakan Ke Tigabelas. Jakarta : Bumi Aksara.

Malayu S.P. Hasibuan, 2014. Manajemen Kinerja dan Kepuasan. Depok. Rajagrafindo Persada Moorhead dan Griffin. 2013. Perilaku Organisasi. Jakarta: Salemba Empat.

Soewadji, J. (2012). Pengantar Metodologi Penelitian. Jakarta : Mitra Wacana Media 
Sutrisno, 2012. Leadership. Gramedia. Jakarta Selatan

Edy, Sutrisno, (2016), Manajemen Sumber Daya Manusia, Kencana Prenada Media Group, Jakarta.

Sugiyono (2015). Metode Penelitian Kombinasi (Mix Methods). Bandung: Alfabeta.

Sugiyono. (2016). Metode Penelitian Kuantitatif, Kualitatif dan R\&D. Bandung: PT Alfabet.

Robbins, P. Stephen. 2008. Organizational Behaviour, Tenth Edition (Perilaku Organisasi Ke Sepuluh), alih bahasa Drs. Benyamin Molan. Salemba Empat: Jakarta.

Robbins, Stephen P. dan Coulter, Mary. 2010. Manajemen Edisi Kesepuluh. Jakarta: penerbit Erlangga

Thomas H.Stone 2011. Manajemen Sumber Daya Manusia Dalam Organisasi Publik dan Bisnis.Edisi kedua.Penerbit ALFABETA.CV

Thoha. Miftah. (2010:52). Perilaku Organisasi. Penerbit : Rineka Jakarta.

Wibowo, 2016. Manajemen Kinerja. Depok. Rajagrafindo Persada.

Jurnal :

Ellisyah Mindari (2018). Pengaruh Kompensasi, Lingkungan Kerja, dan Kepemimpinan Terhadap Kepuasan Kerja. Jurnal Manajemen

Hadinata, Himawan. (2014). Pengaruh Lingkungan Kerja dan Kompensasi Terhadap Kepuasan Kerja Karyawan Pabrik Genteng Massoka, Kebumen Jawa Tengah, Skripsi.

Hendro Tamali (2019) Pengaruh Kompensasi, Kepemimpinan, dan Lingkungan Kerja Terhadap Kepuasan Kerja. Jurnal Manajemen.

Hidayat, Rachmad (2013). Pengaruh Kepemimpinan Terhadap Komunikasi, Kepuasan Kerja dan Komitmen Organisasi Pada Industri Perbankan. Makara Seri Sosial Humaniora. 17(1) : $19-32$

Rohmah, Dede Siti. 2015. "Pengaruh Kepemimpinan, Kompensasi , dan Lingkungan Kerja terhadap Kepuasan Kerja Pada Kantor Pelayanan Pajak”. Jurnal

Yudha, Kresna (2018). Pengaruh Kompensasi Terhadap Kepuasan Kerja Karyawan PT. Pegadaian Syariah Kantor Cabang Simpang Patal Palembang.

Wongkar, Sepang, Loindong. (2018). Pengaruh Lingkungan Kerja, Pelatihan dan Pemberdayaan Sumber Daya Manusia Terhadap Kepuasan Kerja Karyawan Pada PT. Bank Sulutgo. Jurnal EMBA. Vol. 6, No. 4 